\title{
Response of Fourwing Saltbush to Periods of Protection
}

\author{
REX D. PIEPER AND GARY B. DONART
}

Highlight: Fourwing salthush plants produced less leader growth after 4 years of continuous cattle browsing than after 3 years of continuous browsing followed by 1 year of protection. Plants in pastures used in a rotation grazing system produced as much leader growth as protected plants.

Fourwing saltbush (Atriplex canescens) (Pursh) Nutt.) is one of the most valuable and widespread shrubs on western ranges. It occurs from North Dakota to Oregon and south to Mexico (Springfield 1970). In New Mexico, it occurs on desert ranges, but is especially valuable on grassland ranges where it represents one of the few sources of green feed during the period of grass dormancy. Studies in Utah (Picper, et al. 1959) and New Mexico (Cordova 1974) showed that fourwing saltbush forage is higher in several important nutritive characteristics, including protein, phosphorus content, and digestibility, than many other shrubs.

In New Mexico fourwing saltbush grows in scattered stands on many range sites where individual plants are often heavily browsed by domestic livestock. In many cases vigor and productive capacity of these plants is reduced under a system of yearlong grazing (Fig. 1).

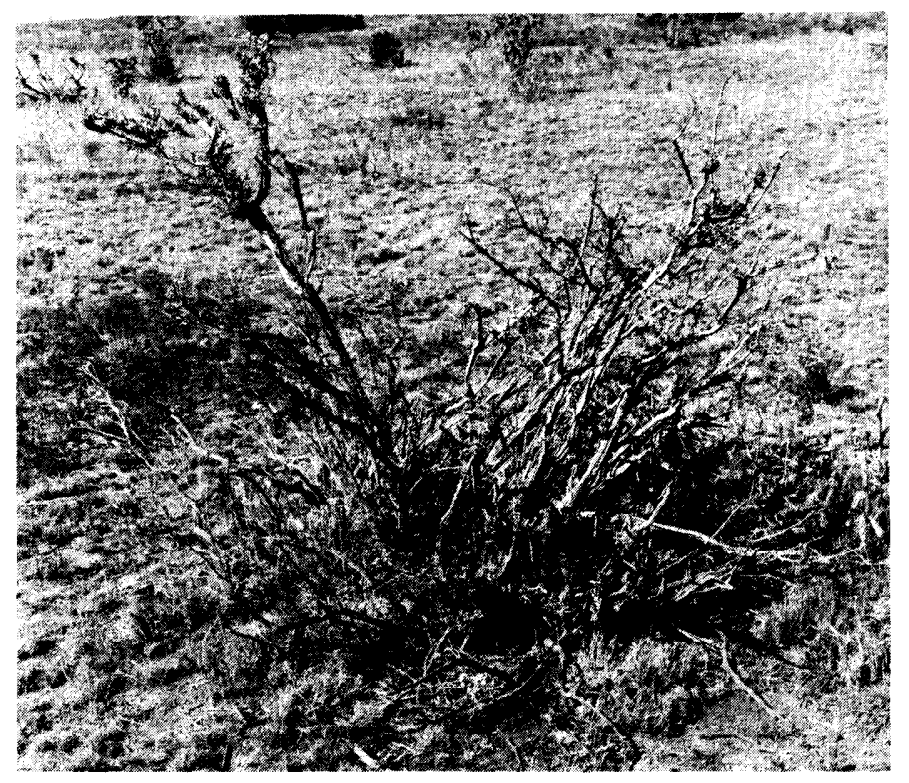

Fig. 1. Severely browsed fourwing saltbush plant in the continuously grazed pasture.

Few studies have been conducted to determine defoliation effects on fourwing saltbush or management systems which enhance fourwing productivity and vigor. Studies in Utah comparing ranges grazed by sheep with those protected from grazing along railroad rights-of-way showed that individual plant cover, number of flower stalks, and annual twig growth was greater for protected fourwing saltbush plants than for grazed plants (Cook and Goebel 1962; Goebel and Cook 1960). Nord and Stallings (1976) reported that excess clipping by rabbits was detrimental to fourwing saltbush plants in California. Buwai and Trlica (1977) found that multiple defoliations reduced production and vigor of fourwing saltbush in Colorado. Other studies (Trlica et al. 1977) showed that rate of recovery of fourwing saltbush

Authors are professor and associate professor of range science, New Mexico State University. Las Cruces 88003

The report is Journal Article 649, Agricultural Experiment Station, New Mexico State Univ. Las Cruces 88003.

Manuscript received subjected to heavy defoliation depended on the phenological stage at time of defoliation.

It was observed that fourwing saltbush plants at the Fort Stanton Experimental Ranch on a pasture used continuously by cattle were browsed very heavily (Fig. 1). Consequently, studies were initiated to compare leader growth of fourwing saltbush plants under different seasons of protection and browsing by cattle.

\section{Methods}

The study area was located on the Fort Stanton Experimental Ranch in south-central New Mexico. The topography is characterized by steep canyons and fairly level mesa tops. Vegetation of the mesas is dominated by blue grama (Bouteloua gracilis H.B.K. Lag.). Annual precipitation just exceeds $37.5 \mathrm{~cm}$ with about $62 \%$ occurring during the growing season.

A small population of fourwing saltbush plants occurring in one portion of a pasture grazed yearlong at a moderate stocking rate was selected for study. A portion of this fourwing saltbush population was included in a 0.8 -ha deer and cattle proof exclosure erected prior to introduction of cattle into the remainder of the pasture in 1969. In 1972 a portion of the population which had been browsed since 1969 was fenced to provide protection from cattle browsing.

In 1973 five individual aerial leaders and five basal leaders were selected at random and measured on ten plants from each of the three treatments: yearlong browsing for 4 years, yearlong browsing for 3 years and protection for 1 year; and complete protection for 4 years.

In 1976 the sampling was repeated on the same plants measured in 1973. Other plants of comparable size were measured in October, 1976 , in a four-pasture, one-herd rotation grazing system that was initiated in 1969 . Plants in the rotation grazing system had been browsed during the growing season about once in 4 years. In the other 3 years, the plants were browsed primarily during the dormant season. In October, 1976, all plants in the various treatments were counted to determine mortality.

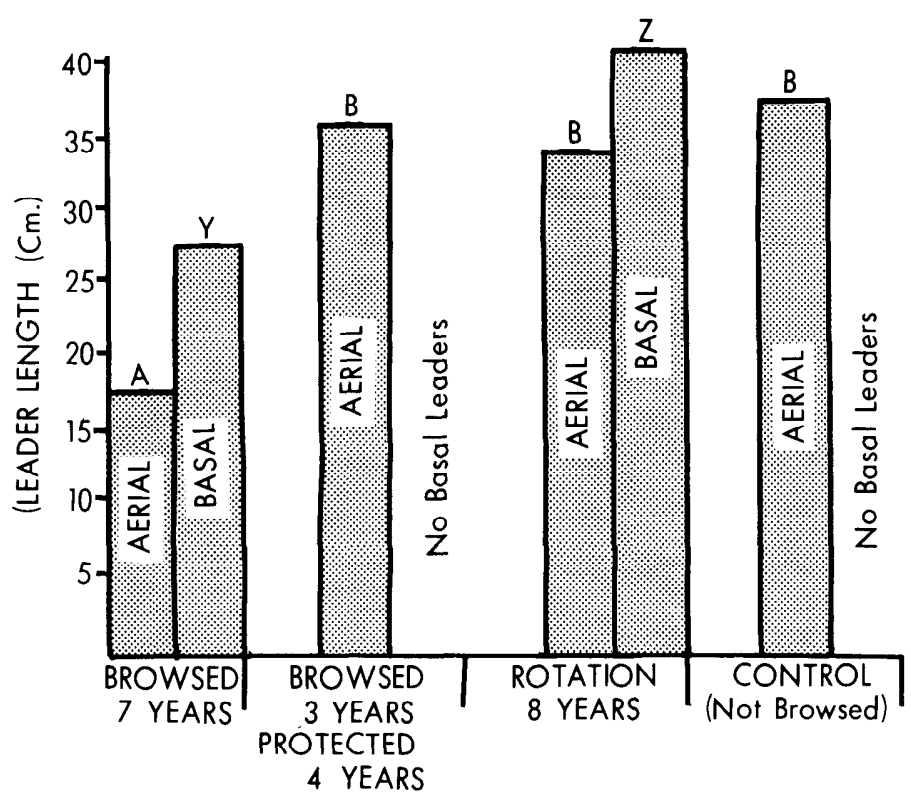

Fig. 2. Average leader length of fourwing saltbush plants under different browsing regimes in 1973. Means with different letters are significantly different $(\mathrm{P}<0.05)$. A, B, C are used for comparison of aerial leaders and $Y$ and $Z$ for basal leaders. 


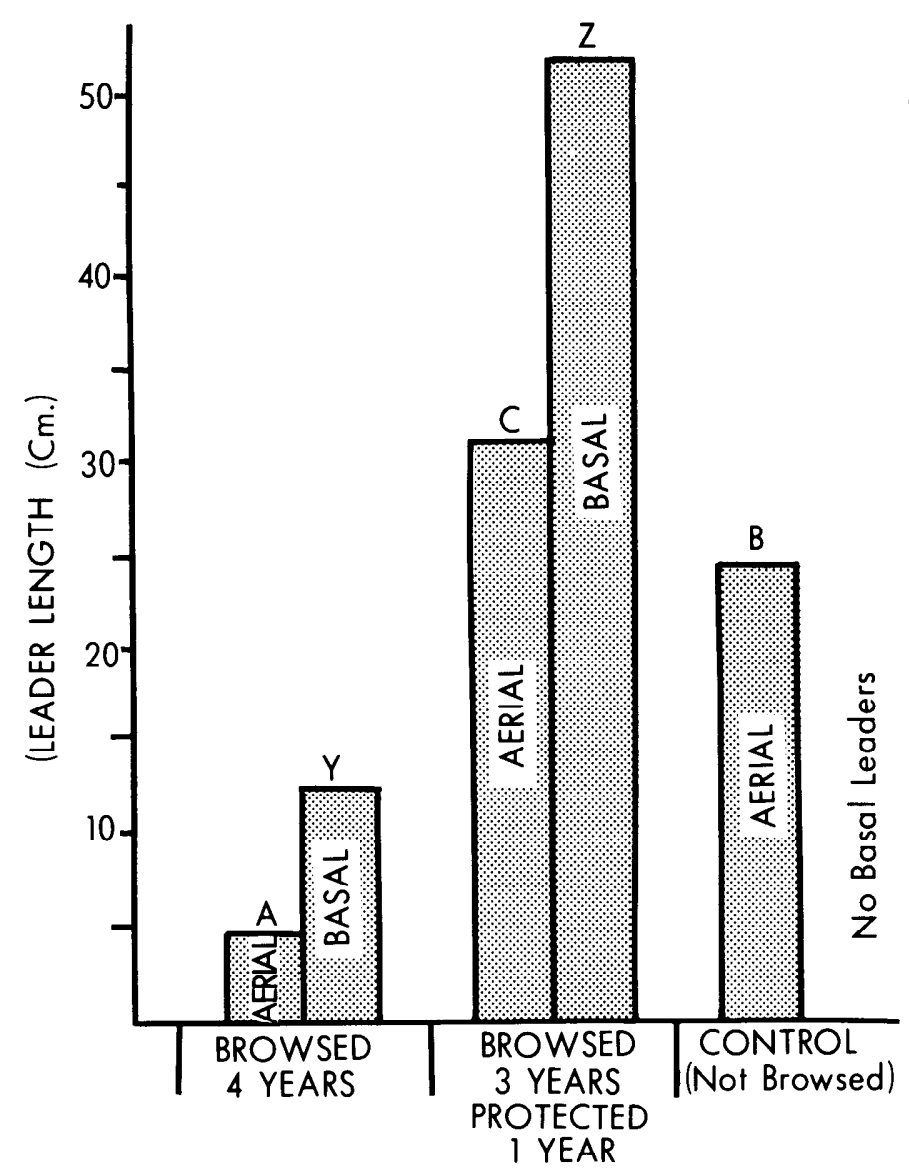

Fig. 3. Average leader length of fourwing saltbush plants under different grazing systems in 1976. Means with different letters are significantly different $(\mathrm{P}<0.05) . A, B, C$ indicate comparisons among treatments for aerial leaders and $Y$ and $Z$ for basal leaders.

\section{Results and Discussion}

Data collected in 1973 indicated that plants browsed continuously for 4 years were producing slightly more than $5 \mathrm{~cm}$ of aerial leader growth annually (Fig. 2). Plants grazed for 3 years and protected for one produced nearly $36 \mathrm{~cm}$ of leader growth, which was slightly more $(P<0.05)$ than that produced by the protected (control) plants. In addition, plants protected 1 year produced nearly $26 \mathrm{~cm}$ more basal leader growth than the continuously browsed plants. Protected plants produced no basal leaders.

Data collected in 1976 were similar to those collected in 1973.
Table 1. Mortality of fourwing saltbush plants under various treatments.

\begin{tabular}{lc}
\hline \hline Treatments & $\begin{array}{c}\text { Percent } \\
\text { mortality }\end{array}$ \\
\hline Grazed yeriong 3 years, protected 4 years & 3.3 \\
Grazed yearlong 7 years & 24.0 \\
Grazed in rotation system 8 years & 0 \\
Control (protected 24 years) & 0 \\
\hline
\end{tabular}

Plants protected from grazing or in the rotation grazing system produced significantly longer $(P<0.05)$ leaders than those plants under continuous browsing (Fig. 3). However, those plants which had been protected for 4 years after being subjected to continuous browsing for 3 years did not produce basal leaders. Apparently, fourwing saltbush basal buds are controlled by apical dominance and responded to terminal bud removal.

Mortality of plants subjected to 7 years of continuous browsing was nearly $25 \%$ of the original stand, while mortality of protected plants in the exclosure or those under the rotation grazing system was zero (Table 1). Less than 5\% of plants browsed for 3 and protected for 4 years died.

Apparently, fourwing saltbush plants in these grassland ranges in New Mexico require periodic rest from continuous utilization to maintain productive, vigorous stands. Cattle in the pasture where the fourwing saltbush plants were growing were stocked at only a moderate rate, yet fourwing saltbush utilization was excessive as shown by low leader growth and high mortality. Reducing the stocking rate to reduce excessive utilization of these plants would probably not be acceptable because other species would be poorly utilized. For plants occurring in moderate to low densities in grassland areas, rest during the growing season appears to be essential once in every 3 or 4 years to maintain these populations.

\section{Literature Cited}

Cook, C. Wayne, and Carl J. Goebel. 1962. The association of plant vigor with physical stature and chemical content of desert plants. Ecology 43: 543-546.

Cordova, Francisco. 1974. Chemical composition and in vitro digestibility of some browse and forb species of southern New Mexico. MS Thesis. New Mexico State Univ., Las Cruces.

Goebel, Carl J., and C. Wayne Cook. 1960. Effect of range condition on plant vigor, production and nutritive value of forage. J. Range Manage. 13:307-313.

Nord, Eamor C., and J. Russell Stallings. 1976. Effects of rabbit clipping on different saltbush species and stains in wildland plantings in southern California. Abstr. Paper presented 29th Annu. Meeting, Society for Range Management, Omaha, Nebraska.

Pieper, Rex, C. Wayne Cook, and Lorin E. Harris. 1959. Effect of intensity of grazing upon nutritive content of the diet. J. Anim. Sci. 18:1031-1037.

Springfield, H. W. 1970. Germination and establishment of fourwing saltbush in the southwest. U.S. Dep. Agr., Forest Serv. Res. Paper RM-55. 